\title{
An ethno-nutritional study on spices used in traditional foods of the Western Regions of Cameroon: the case of nah poh
}

\author{
Stève Djiazet ${ }^{1}$, Laurette Blandine Mezajoug Kenfack ${ }^{2 *}$, Michel Linder ${ }^{3}$ and Clergé Tchiégang ${ }^{1}$
}

\begin{abstract}
The consumption rate of traditional foods is gradually being reduced with time due to the globalization of the food systems and non-availability of modernized ready-to-use traditional food products. In order to contribute to the sustainability and to promote the consumption of nah poh, the present study was undertaken to gather traditional culinary knowledge related to the consumption of some local spices in nah poh, as to contribute to the development of a ready-to-use spice formulation. It consisted in carrying out a qualitative and quantitative survey. The study revealed that there is a great variability with respect to the different Divisions of the Western Regions of Cameroon, regarding the spice composition of nah poh. All the local spices used for this study are utilized for the preparation of nah poh. Seven spices were found to be essential in most Divisions. Scorodophloeus zenkeri fruits and Xylopia africana were shown to be essential spices for consumers in Mezam Division. The quantities of essential spices for one litre of nah poh varied between $0.61 \pm 0.24 \mathrm{~g}$ and $4.59 \pm 2.06 \mathrm{~g}$.
\end{abstract}

Keywords: nah poh, Preparation, Local spices, Variability, Western Regions of Cameroon

\section{Practical applications}

During food product development, the sensory characteristics are not often planned right at the beginning of the process. The practical aspect in the present study is to use a statistical approach to identify the type of spices that can influence the sensorial properties of the end product, to quantify them and also to have the acceptability ranges of the different components that would be used for the designing step of the product. This will enable us during future studies to formulate spice prototypes with a high probability of being accepted by most consumers of nah poh, to reduce the number of experiments and to gain on expenditure and time.

\section{Introduction}

Worldwide, Traditional foods suffer from many problems including inadequate intergenerational knowledge transfer, lack of documentation and time-consuming processes,

\footnotetext{
* Correspondence: mezajouglaurette@yahoo.fr

Department of Agriculture, Breeding and Derived Products, National

Advanced School of Engineering, University of Maroua, PO Box 46, Maroua,

Cameroon

Full list of author information is available at the end of the article
}

among others [1-4]. Most traditional foods require a diversity of edible plant materials for their preparation. As such, the mastering of components and processing methods constitute limitations to the valorization of this category of foods. Among the solutions suggested to promote the consumption of traditional foods are their documentation and the development of modernized form of ready-to-use food products. Product development requires culinary knowledge applied during the preparation so as to maintain the indigenous or traditional practices [3].

Yellow achu soup, also known as nah poh, suffers from these problems, unlike other traditional foods. It is an emulsion of crude palm oil in water, stabilized by kanwa or aqueous extract of ash from plant materials, especially banana peelings (niky), in which a mixture of ground local spices is added (Fig. 8a-d). The soup is eaten with $a c h u$, obtained by pounding the tubers of Colocasia esculenta. In the dialects of the ethnic group living in the West Region of Cameroon, nah refers to soups in general, and poh refers to a paste obtained from pounded tubers of C. esculenta. The meal is a delicacy during death and birth celebrations, other traditional events in the Western Regions of Cameroon and during cultural festivities involving

(C) The Author(s). 2019 Open Access This article is distributed under the terms of the Creative Commons Attribution 4.0 International License (http://creativecommons.org/licenses/by/4.0/), which permits unrestricted use, distribution, and 
people from Cameroon worldwide. This soup requires spices that are either harvested from the forests or cultivated by the indigenous population.

More than nineteen (19) different spices are used for the preparation of nah poh [5]. Previous studies on the spices used for the preparation of this soup showed that they are a source of many essential nutrients and possess health benefits $[1,5-7]$. However, their primary uses are in the form of spices in traditional foods and as medicinal plants in many ethnic groups of West and Central Africa. Each meal has some characteristics that differentiate it from others. When spices are mixed appropriately, they play an important role on the sensory viewpoint, by providing a particular taste and flavour to a meal. The relationship between spices and sensory attributes also have been established [8]. The mixture of spices requires the determination and use of appropriate type and quantity of each entity because each spice provides a/or particular compound(s) that stimulates a particular sensory receptor or produces a crossmodal effect due to the various sensory modalities [9]. Very few published documents have intended to valorize these less-known spices through traditional foods, especially nah poh. Their valorization as such faces a certain number of problems like differences in the way of using them in the various localities within the ethnic groups where nah poh originated; crushing the spices to make spice paste for the soup is time consuming $[2,10]$. This study intends to gather traditional culinary knowledge related to the consumption of local spices for nah poh as to contribute to the development of a modernized form of ready-to-use spice formulation with accepted sensory requirements. The development of a safe and accepted food product from these spices would contribute to culinary tourism, diversification of food habits and the cultural propaganda of the ethnic groups and the country as a whole.

\section{Materials and methods Materials}

Twenty-four (24) spices were identified from literature and a preliminary survey with local spice sellers in Bafoussam and Bamenda. Samples used for this study were bought in 'marché B' Bafoussam and Food Market Bamenda, West and North-West Regions of Cameroon respectively. The spices samples included fruits, roots and bark of trees. Their scientific names, some English

Table 1 Scientific names, abbreviations and parts of plants of the samples

\begin{tabular}{|c|c|c|c|}
\hline Scientific names & English names & Abbreviations & Parts of plant used \\
\hline -Aframomum daniellii (Hook. F) K. Schum & Bastred melegueta & $(\mathrm{Ad})$ & Fruits \\
\hline -Aframomum sp. & - & (As) & \\
\hline -Capsicum frutescens $\mathrm{L}$. & Bird pepper & (Ca) & \\
\hline -Dichrostachys glomerata (Forsk.) Hutch. & Sickle bush & $(\mathrm{Dg})$ & \\
\hline -Fagara leprierii Guill. and Perr. & Prickly ash & $(\mathrm{Fl})$ & \\
\hline -Fagara xanthozylö̈des Watern. & - & $(F x)$ & \\
\hline -Hua gabonii Pierre & Garlic tree & $(\mathrm{Hg})$ & \\
\hline -Monodora myristica Gaertn. & Calabash nutmeg & $(\mathrm{Mm})$ & \\
\hline -Piper capense Wild & Cordoncillo & $(\mathrm{Pc})$ & \\
\hline -Piper guineense Schun and Thonn. & Black pepper (Ashandi) & $(\mathrm{Pg})$ & \\
\hline -Scorodophloeus zenkeri Harms. & Divida (African) & (Sz) & \\
\hline -Solanum melongena L. Var Inerme D. C. Hlern & Aubergine & $(\mathrm{Sm})$ & \\
\hline -Tetrapleura tetraptera Schun and Thonn Thaub & Aidan tree & $(T t)$ & \\
\hline -Xylopia aethiopica Dunal A. Rich & Ethiopian pepper (African) & $(X a e)$ & \\
\hline -Xylopia africana (Benth.) Oliv & - & $(\mathrm{Xa})$ & \\
\hline -Xylopia parviflora (A. Rich) Benthane & - & $(X p)$ & \\
\hline -Dorstenia psilurus Welw. & - & (Dp) & Roots \\
\hline -Echinops giganteus A. Rich. & Giant Japanese butterbur & (Eg) & \\
\hline -Mondia whitei (Hook F). Skell. & White ginger & $(\mathrm{Mw})$ & \\
\hline -Pentadiplandra brazzeana Var Brazzeana & Joy perfume tree & $(\mathrm{Pb})$ & \\
\hline -Scleria striatinux De Wild. & - & (Ss) & \\
\hline -Hua gabonii Pierre & Garlic tree & $\mathrm{Hgb}$ & Bark of plants \\
\hline -Hypodaphnis zenkeri (Engler) Stapf & - & $\mathrm{Hz}$ & \\
\hline -Scorodoploeus znkeri Harms & Divida (African) & Szf & \\
\hline
\end{tabular}


or common names and respective abbreviation in brackets are the found in Table 1:

\section{Localities of study}

The study done by Abdou Bouba [2] in the ten (10) Regions of Cameroon showed that plants used as spices in yellow achu soup were well known in the Western Regions of Cameroon than the rest of the Regions. Though the meal is eaten all over the country and even abroad, the study area chosen was its place of origin. For this reason, the survey was carried out in the West, NorthWest and South-West Regions of Cameroon, as shown in Table 1. It also gives the Divisions, localities and the number of people interviewed. Table 2 gives the geographical coordinates and the number of people interviewed in the different Divisions while Fig. 1 presents the map of the localities where the survey was done.

\section{Questionnaire}

A series of thirty (30) questions were exploited to collect information related to the use of local spices for the preparation of nah poh and other meals in which the spices are used. Utilisation frequencies, qualitative and quantitative studies related to the use of each of the spices in nah poh were the main points investigated. The parts of the inquiry exploited to write the present paper constitute a sub-heading of the questionnaire used for the research project on utilisation value of these spices in the West Regions of Cameroon.

\section{Methods}

The methodology used was similar to the one exploited in our previous paper on the use of these spices for $n k w i$, following that of Badau et al. [11] in a similar study carried out in Nigeria. The survey took place between August and
October 2013. A total of 517 women were questioned on the following aspects:

- Acknowledgment frequency of each local spice

The acknowledgment frequency helps to verify that the information collected concerning a particular spice is not far different from the reality, as to come out with results that can be exploited for the development of a spice formulation acceptable by consumers. The acknowledgment frequency of each local spice is the ratio of individuals who know a particular spice over the number of people interviewed times 100.

$$
A f=\frac{\mathrm{Nk}}{\mathrm{Ni}} 100
$$

Af: acknowledgment frequency

Nk: number of individuals who know a particular spice

Ni: number of individuals interviewed

All the spice samples were presented to woman interviewed to identify the known spices.

\section{- Spices used for the preparation of nah poh}

Each woman interviewed was asked to identify the spices known and used by her to prepare nah poh following the outlines below.

- Essential spices of nah poh

- Spices responsible of the taste of nah poh

- Spices responsible of the odour of nah poh

Essential spices for nah poh are spices without which the soup obtained could not have the sensorial characteristics

Table 2 Places where the survey was carried out and number of interviews

\begin{tabular}{|c|c|c|c|c|}
\hline Regions & Divisions & Localities & Geographical coordinates & $\begin{array}{l}\text { Number of people } \\
\text { interviewed }\end{array}$ \\
\hline \multirow[t]{7}{*}{ West } & Upper-Nkam (UN) & Bafang, Banka & $5^{\circ} 09^{\prime} 00^{\prime \prime} \mathrm{N} / 10^{\circ} 10^{\prime} 60^{\prime \prime} \mathrm{E}$ & 30 \\
\hline & Upper-Plateau (Up) & Baham, Bangou & $5^{\circ} 20^{\prime} 04^{\prime \prime} \mathrm{N} / 10^{\circ} 22^{\prime} 08^{\prime \prime} \mathrm{E}$ & 34 \\
\hline & Koung-Khi (Kk) & Bandjoun & $5^{\circ} 22^{\prime} 31^{\prime \prime} \mathrm{N} / 10^{\circ} 24^{\prime} 44^{\prime \prime} \mathrm{E}$ & 32 \\
\hline & Nde (N) & Bangangte & $5^{\circ} 09^{\prime} 00^{\prime \prime} \mathrm{N} / 10^{\circ} 31^{\prime} 00^{\prime \prime} \mathrm{E}$ & 40 \\
\hline & Bamboutos (Bam) & Bangang, Mbouda, Balatchi & $5^{\circ} 37^{\prime} 60^{\prime \prime} \mathrm{N} / 10^{\circ} 15^{\prime} 00^{\prime \prime} \mathrm{E}$ & 85 \\
\hline & Mifi (Mi) & Bamegoum, Baleng Bafoussam & $5^{\circ} 28^{\prime} 60^{\prime \prime} \mathrm{N} / 10^{\circ} 24^{\prime} 00^{\prime \prime} \mathrm{E}$ & 54 \\
\hline & Menoua (Me) & Bansoa, Bafou, Dschang & $5^{\circ} 27^{\prime} 00^{\prime \prime} \mathrm{N} / 10^{\circ} 04^{\prime} 00^{\prime \prime} \mathrm{E}$ & 80 \\
\hline \multirow[t]{4}{*}{ North West } & Mezam (Mez) & Nkwen & $5^{\circ} 58^{\prime} 43^{\prime \prime} \mathrm{N} / 10^{\circ} 08^{\prime} 52^{\prime \prime} \mathrm{E}$ & 30 \\
\hline & & Santa & & 30 \\
\hline & & Bafut & & 30 \\
\hline & & Mankon & & 30 \\
\hline South-West & Lebialem (Le) & M'Muock-Fosimundi, M' Muock-Leteh & $5^{\circ} 42^{\prime} 47^{\prime \prime} \mathrm{N} / 10^{\circ} 03^{\prime} 54^{\prime \prime} \mathrm{E}$ & 42 \\
\hline Total & & & & 517 \\
\hline
\end{tabular}




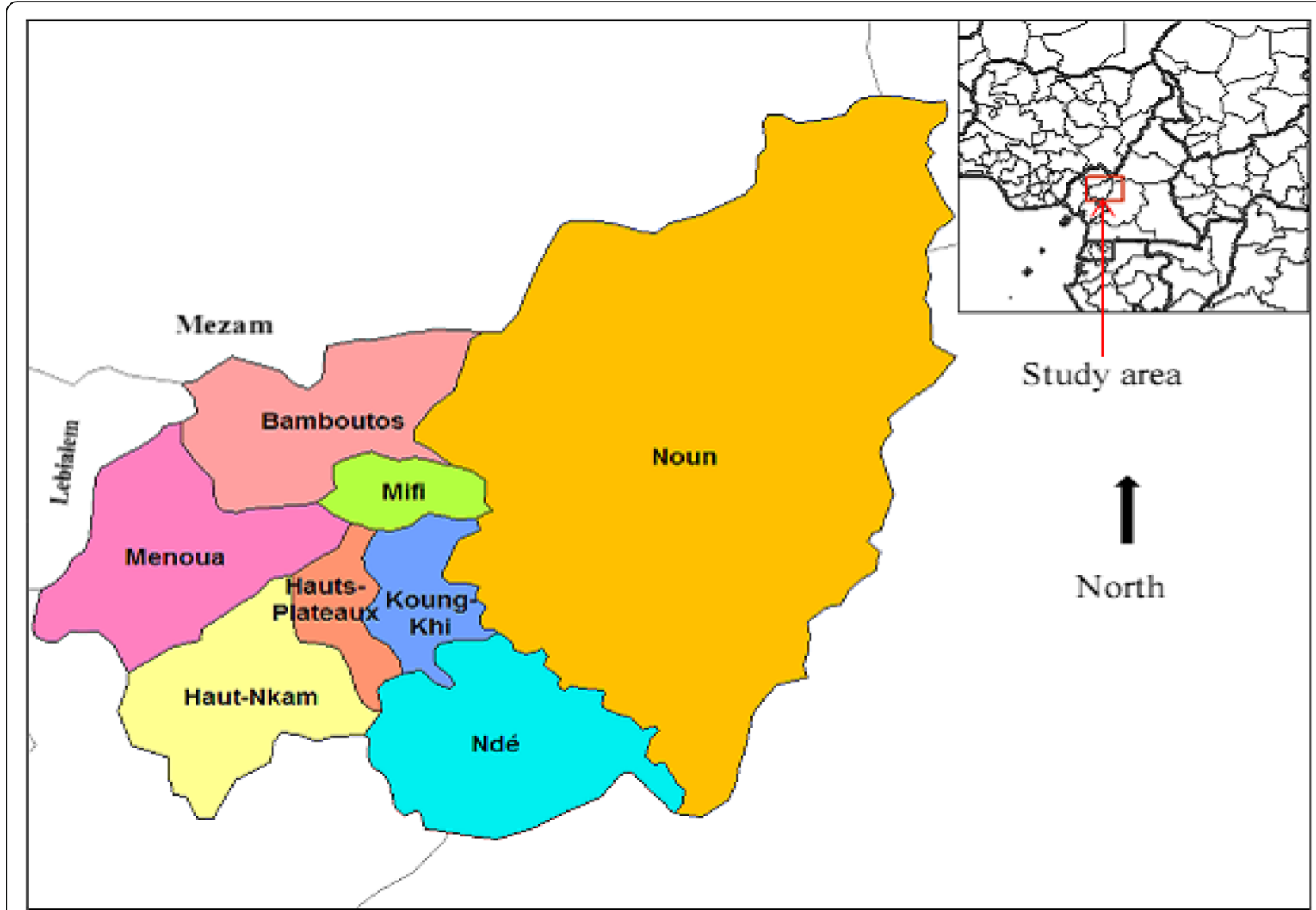

Fig. 1 Map of the study area. The study area is made up of the three western regions of Cameroon. A total 10 divisions and 23 localities were included in the study. They are all found in the high land areas and people living there have almost the same culture. Ethnic groups living in these villages are attached to their cultural practices, including the foods that are eaten there. UN: Upper Nkam; Mi: Mifi; UP: Upper Plateau; Mez: Mezam; KKi: Koung-Khi; N: Nde; Me: Menoua; Le: Lebialem; Bam: Bamboutos; Ba: Bansoa Ad: A. daniellii; As: A. sulcatum; Ca: C. frutescens; Dg: D. glomerata; Dp: D. psilurus; Eg: E. giganteus; Fl: F. leprierii; Fx: F. xanthozyloides; Hgb: H.gabonii (bark); Hgf: H. gabonii (fruits); Hz: H. zenkeri; Mw: M. whitei; Mm: M. myristica; Pb: P. brazzeana; Pc: P. capense; Pg: P. guineense; Ss: S. striatinux; Szf: S. zenkeri fruit; Szb: S. zenkeri (bark); Sm: S. melongena; Tt: T. tetraptera: Xae: X. aethiopica; Xa: X. africana; Xp: X. parviflora

expected for nah poh. Each individual interviewed was asked to select the spices employed by her as essential for the preparation of nah poh; as well as those that provide the taste and odour of the soup respectively.

- Quantities of each essential spices used for the preparation of nah poh

Each individual interviewed was asked to remove from each of the identified spices samples used by her, the quantity necessary for the preparation of one litre of nah poh. The quantity proposed was immediately weighed and the value recorded for each sample.

\section{Statistical analysis of data}

Data collected were introduced in Sphinx v5 Plus ${ }^{2}$ Lexica Edition in order to determine the frequency of each modality and the mean weights of each spice used for the preparation of nah poh. Tabulated data were introduced in XL STAT 2014 version in order to carry out the principal components analysis which gives the correlation between each of the local spice samples and the different Divisions.

\section{Results and discussion}

Table 3 presents the results of acknowledgment frequency in percentages (\%) of each of the local spices with respect to the Division of residence in the study area.

Table 3 shows that the 24 spices are well known by the populations of the West Region than those of North-West and South-West Regions of Cameroon. Three of these spices $X$. africana (Xa), S. zenkeri (bark) (Szb) and Aframomum sulcatum (As) are generally not well known. Nevertheless, $X$. africana is well known in Mezam Division (94.1\%) meanwhile it is almost not 
Table 3 Acknowledgment frequency of each spice (\%) with respect to the Divisions of residence

\begin{tabular}{|c|c|c|c|c|c|c|c|c|c|c|c|}
\hline \multirow[t]{2}{*}{ Spices } & \multicolumn{11}{|c|}{ Divisions } \\
\hline & UN & $\mathrm{Mi}$ & UP & hez & $\mathrm{KKi}$ & $\mathrm{N}$ & $\mathrm{Ba}$ & $\mathrm{Me}$ & Le & Bam & Tota \\
\hline & 100 & 100 & 100 & 5.6 & 100 & 100 & 100 & 100 & 87 & 100 & 93.4 \\
\hline$\Delta c$ & 12.9 & 17 & 18.8 & 5.0 & 12.5 & 2.5 & 0 & 2.1 & 2.6 & 2.4 & 6.8 \\
\hline & 00 & 100 & 100 & 6.6 & 100 & 100 & 100 & 100 & 97 & 100 & 9 \\
\hline & & 97 & 100 & 89.9 & 100 & 100 & 97.1 & 98 & 79 & 100 & 054 \\
\hline & & 98 & 100 & & 100 & 100 & 94.1 & 96 & 76 & 98.8 & \\
\hline & 100 & 98 & 100 & 48.7 & 100 & 100 & 91.2 & 94 & 71 & 92.9 & 836 \\
\hline & 100 & 100 & 100 & 96.6 & 100 & 100 & 100 & 100 & 84 & 100 & \\
\hline & 100 & 100 & 100 & 80.7 & 100 & 100 & 100 & 100 & 90 & 100 & 948 \\
\hline & 100 & 98 & 100 & 91.6 & 100 & 100 & 100 & 100 & 100 & 100 & \\
\hline gf & 100 & 100 & 100 & 97.5 & 100 & 100 & 100 & 100 & 92 & 10 & 98.8 \\
\hline & 90.3 & 100 & 100 & 31.9 & 93.8 & 98 & 88.2 & 96 & 71 & 92.9 & \\
\hline & 100 & 100 & 100 & 83.2 & 100 & 100 & 100 & 100 & 76 & & \\
\hline & 100 & 100 & 96.9 & 99.2 & 100 & 100 & 100 & 100 & 97 & 98.8 & \\
\hline & 100 & 100 & 100 & 94.1 & 100 & 100 & 97.1 & 100 & 79 & 3.8 & \\
\hline & 67.7 & 88 & 96.9 & 31.1 & 90.6 & 85 & 79.4 & 64 & 50 & 66.7 & \\
\hline & 100 & 100 & 100 & 96.6 & 100 & 100 & 100 & 100 & 97 & 98.8 & 98.8 \\
\hline & 100 & 100 & 100 & 89.9 & 100 & 100 & 100 & 100 & 76 & 98.8 & 95.7 \\
\hline$z b$ & 3.2 & 6.8 & 0 & 1.7 & 0 & 0 & 2.9 & 2.1 & 0 & 10.7 & 3.5 \\
\hline & 100 & 100 & 100 & 97.5 & 100 & 100 & 100 & 100 & 97 & 98.8 & 99 \\
\hline & 100 & 100 & 100 & 79.8 & 100 & 100 & 100 & 100 & 84 & 100 & 94.2 \\
\hline & 100 & 100 & 100 & 95 & 100 & 100 & 100 & 100 & 84 & 100 & 97.7 \\
\hline & 100 & 98 & 100 & 88.2 & 100 & 100 & 100 & 100 & 84 & 100 & 95.9 \\
\hline & 6.5 & 1.7 & 0 & 94.1 & 3.1 & 0 & 0 & 0 & 34 & 0 & 25 \\
\hline kp & 100 & 98 & 100 & 91.6 & 100 & 100 & 97.1 & 98 & 66 & 98.8 & 94.8 \\
\hline
\end{tabular}

UN: Upper Nkam; Mi: Mifi; UP: Upper Plateau; Mez: Mezam; KKi: Koung-Khi; N: Nde; Me: Menoua; Le: Lebialem; Bam: Bamboutos; Ba: Bansoa Ad: A. daniellii; As: Aframomum sulcatum; Ca: C. frutescens; Dg: D. glomerata; Dp: D. psilurus; Eg: E. giganteus; Fl: F. leprierii; Fx: F. xanthozyloides; Hgb: H.gabonii (bark); Hgf: H. gabonii (fruits); Hz: H. zenkeri; Mw: M. whitei; Mm: M. myristica; Pb: $P$. brazzeana; Pc: P. capense; Pg: P. guineense; Ss: S. striatinux; Szf: S. zenkeri fruit; Szb: S. zenkeri (bark); Sm: S. melongena; Tt: T. tetraptera: Xae: X. aethiopica; Xa: $X$. africana; $X \mathrm{p}: X$. parviflora. The bold lines are spice sample which are not generally known but are utilized specifically in certain divisions

known in the rest of the Divisions. The spices that were not well known were spices that grow specifically in some places $[12,13]$. It was found that $S$. zenkeri plant is mostly exploited for its fruits meanwhile H. gabonii it is ok are said not to produce fruits in some localities and are therefore exploited for their barks which has the same aroma as the fruits. The fact that the spices are well known assures that the information gathered relative to their use in nah poh is reliable.

\section{Spices used for the preparation of nah poh}

Figure 2 is the principal components analysis which groups the different spices with respect to the Divisions and gives an idea on their uses in these Divisions as spice used for the preparation of nah poh. The red lines and points represent the different Divisions and the blue points, the spices samples.

There are two major ways of making the spice mixes for nah poh: a mix proper to Mezam and Lebialem Divisions and almost a common way of making the spice mix in the different Divisions of the West Region. Sixteen (16) different local spices are mostly used in the West Region for the preparation of nah poh. In the North-west and Southwest Regions, eleven (11) spices are often used; this justifies the isolation of these two Divisions on Fig. 2. In the West Region of Cameroon, there also exist differences in making the spice mixture of nah poh from one Division to the other. The differences are materialized on Fig. 2 by the gap that separates a red line from the other. The spice composition of nah poh is almost the same in Menoua and Bamboutos Divisions; thus the superposition of the red lines representing these two Divisions. The spices that are most often used for the preparation of nah poh are found on the positive side of the F2 axis; that is on the right of the F1 axis. They include C. frutescens (Ca), D. glomerata (Dg), H. gabonii (Hg), M. myristica (Mm), P. guineense (Pg), T. tetraptera (Tt), X. aethiopica (Xae), D. psilurus (Dp), E. giganteus (Eg), S. striatinux (Ss), H. gabonii bark $(\mathrm{Hgb})$ and $H$. zenkeri $(\mathrm{Hz})$. Spices that are not often used for the preparation of nah poh are on the left of F1 axis and are concentrated along the negative side of the F2 axis; they include $A$. sulcatum (As), F. leprierii (Fl), F. xanthozyloïdes (Fx), S. melongena (Sm), X. parvifora (Xp), M. whitei (Mw), P. brazzeana $(\mathrm{Pb})$ and $S$. zenkeri (Sz) fruits. It is to be noted that though $X$. africana (Xa) and $S$. zenkeri $(\mathrm{Sz})$ fruits are found on the left side of the F1 axis, they are the spices that are mostly employed in Mezam Division and are almost not used in the Divisions of the West Region; thus their closeness to Mezam Division. $P$. capense $(\mathrm{Pc})$ and $A$. daniellii (Ad) are isolated in the left side of the F1 axis because they are used in Koung-Khi, Nde, Upper-Plateau and Upper-Nkam Divisions and are almost not used in other Divisions, especially Mezam and Lebialem. It is for this reason that they are close to Koung-Khi, Nde, Upper-Plateau and UpperNkam Divisions in Fig. 2.

\section{Essential spices of nah poh and correlations with the Divisions of the study area}

Essential spices of nah poh are the spices without which the required sensorial properties of the soup prepared cannot be met. They differ from a place to the other and play an important role in the sensorial qualities of the soup.

\section{Spices generally considered as essential for nah poh}

Figure 3 presents the spices that are generally considered essential for nah poh in all the Divisions of the study area. 


\section{Biplot (axes F1 and F2: 85,93 \%)}

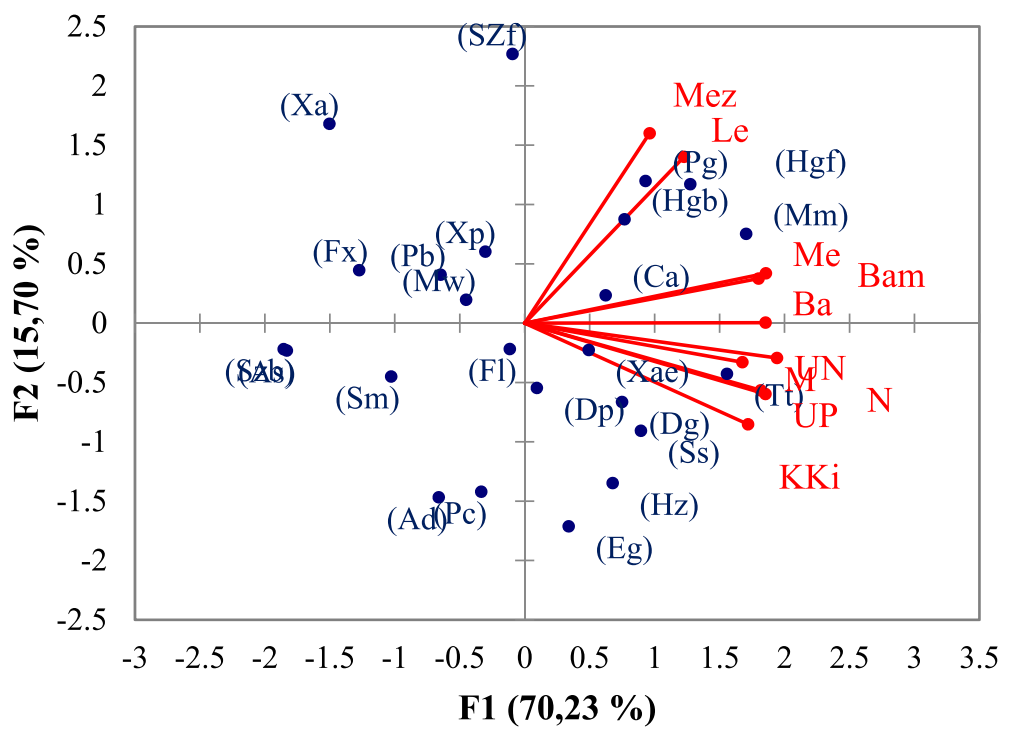

Fig. 2 Spices used for the preparation of nah poh with respect to the Divisions. The figure gives the relationship between each spice and its utilisation in the corresponding divisions as spice use for the preparation of nah poh. F1 and F2 axes contribute to explain the relationship between the spices and the divisions where it is consumed at $85.93 \%$. Spice are represented by blue points, and the corresponding name is written beside. Divisions are represented by red points and lines. The more a spice is closer to a division, the more there is an affinity with the said spice to that division. UN: Upper Nkam; Mi: Mifi; UP: Upper Plateau; Mez: Mezam; KKi: Koung-Khi; N: Nde; Me: Menoua; Le: Lebialem; Bam: Bamboutos; Ba: Bansoa Ad: A. daniellii; As: A. sulcatum; Ca: C. frutescens; Dg: D. glomerata; Dp: D. psilurus; Eg: E. giganteus; Fl: F. leprierii; Fx: F. xanthozyloides; Hgb: H.gabonii (bark); Hgf: H. gabonii (fruits); Hz: H. zenkeri; Mw: M. whitei; Mm: M. myristica; Pb: P. brazzeana; Pc: P. capense; Pg: P. guineense; Ss: S. striatinux; Szf: S. zenkeri fruit; Szb: S. zenkeri (bark); Sm: S. melongena; Tt: T. tetraptera: Xae: X. aethiopica; Xa: X. africana; Xp: X. parviflora

\section{Observations (axes F1 and F2: 87,85\%)}

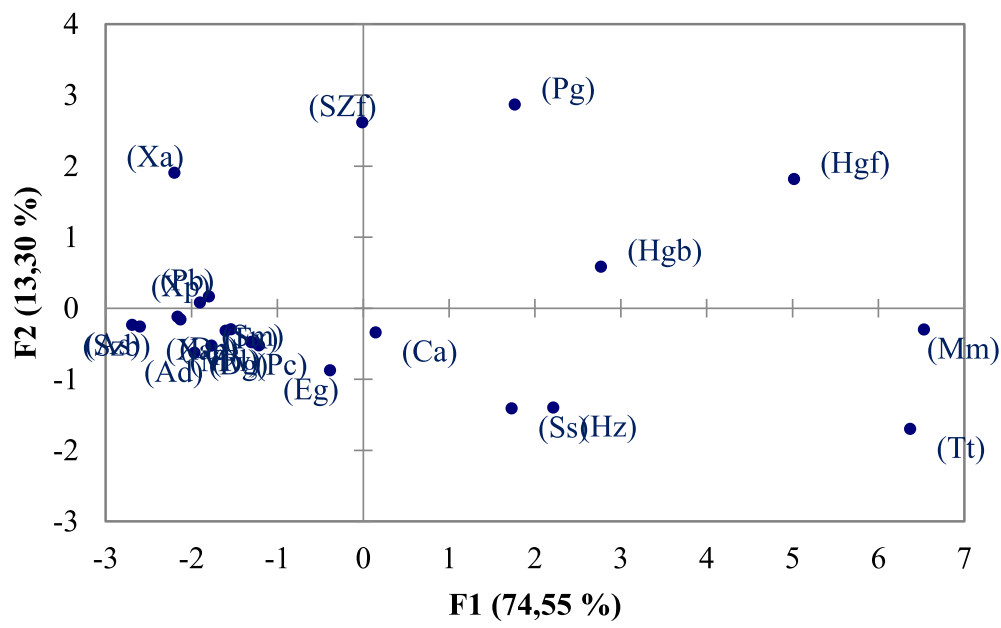

Fig. 3 Representation of spices generally considered as essential for nah poh on F1F2 axes. The figure presents essential spices for nah poh. F1 and F2 axes contribute to explain the use of each of the spices presented as essential spice at $87.85 \%$. This figure shows that 10 spices out of 24 are important for the preparation of nah poh in the study area as a hole. The spices represented toward the positive side of the axes are considered as essential by most people for the preparation of nah poh. The spices grouped on the left side are those that are not essential for the preparation of nah poh. UN: Upper Nkam; Mi: Mifi; UP: Upper Plateau; Mez: Mezam; KKi: Koung-Khi; N: Nde; Me: Menoua; Le: Lebialem; Bam: Bamboutos; Ba: Bansoa Ad: A. daniellii; As: A. sulcatum; Ca: C. frutescens; Dg: D. glomerata; Dp: D. psilurus; Eg: E. giganteus; Fl: F. leprierii; Fx: F. xanthozyloides; Hgb: H.gabonii (bark); Hgf: H. gabonii (fruits); Hz: H. zenkeri; Mw: M. whitei; Mm: M. myristica; Pb: P. brazzeana; Pc: P. capense; Pg: P. guineense; Ss: S. striatinux; Szf: S. zenkeri fruit; Szb: S. zenkeri (bark); Sm: S. melongena; Tt: T. tetraptera: Xae: X. aethiopica; Xa: X. africana; Xp: X. parviflora 
It appears clearly in Fig. 3 that M. myristica and T. tetraptera are the most appreciated essential spices for the preparation of nah poh, followed by H. gabonii fruits. P. guineense, S. striatinux H. gabonii bark, $H$. zenkeri bark $C$. frutescens, $X$. africana and $S$. zenkeri fruits taking into consideration their positions when projected on the F2 axis. All the spices that are grouped along the negative part of the F2 axis are not essential for the preparation of nah poh.

\section{Relationship between essential spices of nah poh and the Division of residence}

Figure 4 presents the relationship between essential local spices of nah poh and the Divisions of residence. The aim of this representation is to determine spices that are considered essential in each Division.

Essential spices for the preparation of nah poh could be separated into three groups taking into consideration the different Divisions where they are part of the food habits. In Mezam Division, essential spices for this soup are $X$. africana, S. zenkeri fruits and $P$. guineense; in Lebialem, $P$. guineense, $H$. gabonii fruits and $H$. gabonii bark are used as essential spices for nah poh. The last group is made up of the different Divisions of the West Region; they include $H$. gabonii fruits, $M$. myristica, $P$. guineense, T. tetraptera, S. striatinux, H. gabonii bark, H. zenkeri bark and C. frutescens. Nana Ngassam [10] in a similar study showed that $P$. guineense was generally considered as the common most essential spice for the preparation of nah poh in Nde, Bamboutos and Mezam Division. Added to $P$. guineense other most essential spices in these localities were $M$. myristica and S. striatinux in Nde Division and M. myristica in Bamboutos Division.

Results of Figs. 3 and 4 show that M. myristica, P. guineense and S. striatinux are essential for nah poh. In addition to these three spices, $T$. tetraptera, H. gabonii fruits, $X$. africana and S. zenkeri fruits are employed as essential spices in certain Divisions. This shows that essential spices of this soup are not common to all the Divisions.

\section{Spices responsible of the taste of nah poh}

Local spices are used in the preparation of many traditional dishes. According to the information collected during the survey, the sensorial characteristics of nah poh can only be met when the right spices are used in the right proportions. Moreover, the quality of a meal is determined by its taste, which in turn depends on the ingredients used [14]. In the case of nah poh, a certain number of spices are used for this purpose. Figure 5 presents the spices used to provide the taste of nah poh with respect to the Divisions of residence in the study area.

Among the essential local spices, some are intentionally used to provide the taste of nah poh. They could be divided into three groups: Mezam, Lebialem and a group made up of the different Divisions of the

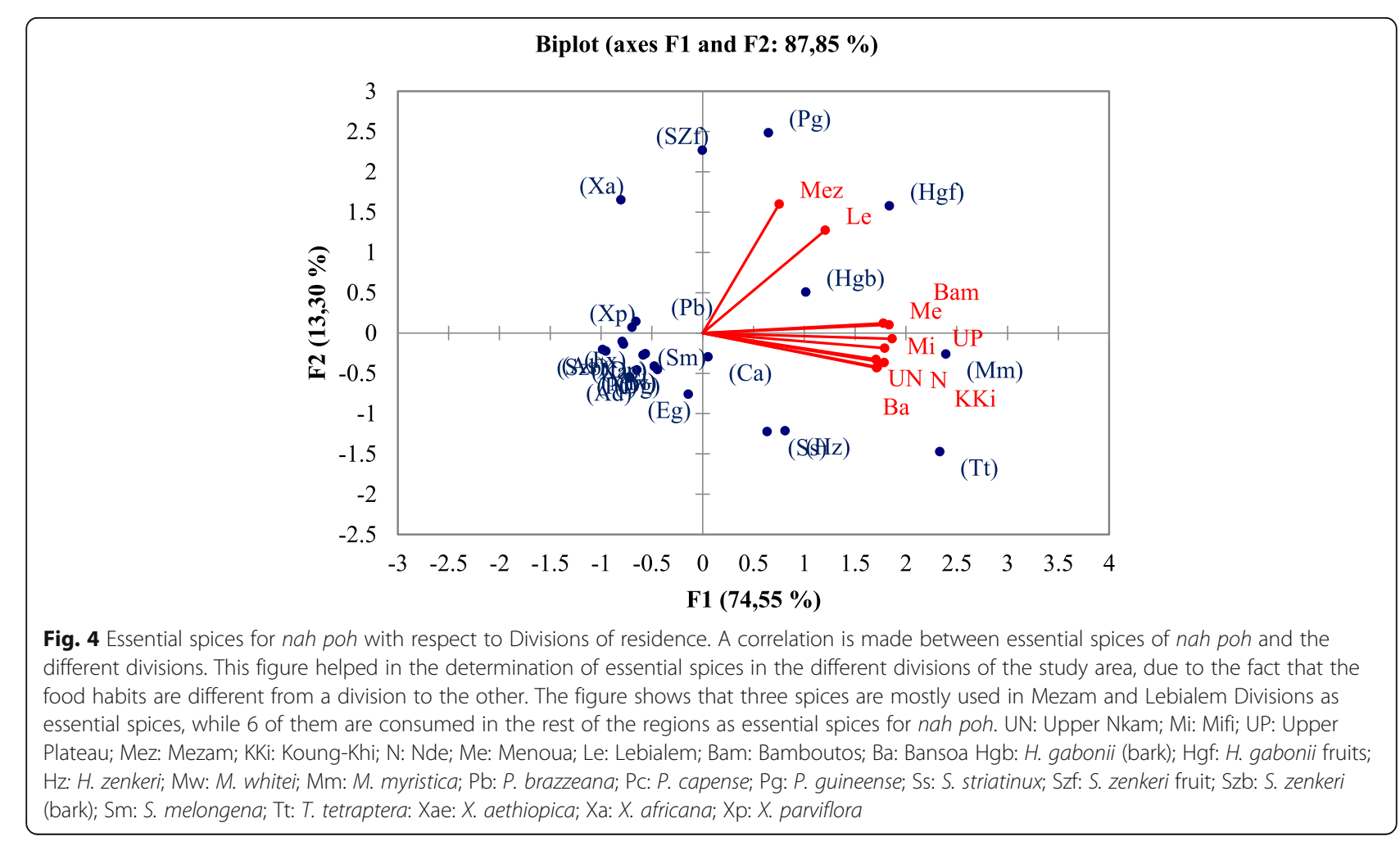


Biplot (axes F1 and F2: 91,89\%)

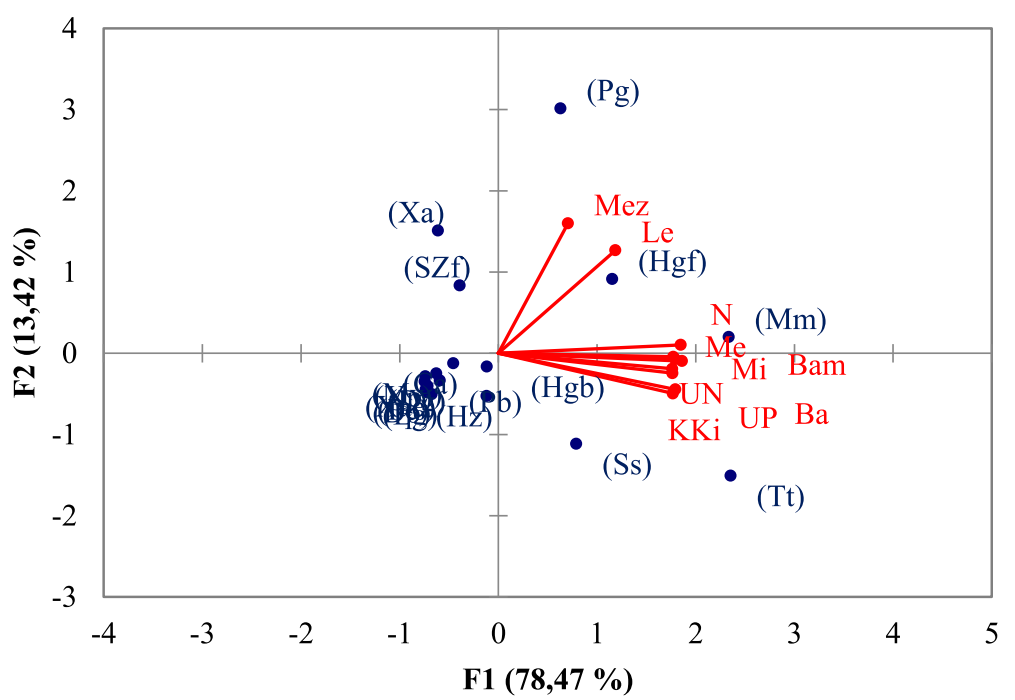

Fig. 5 Spices responsible of the taste of nah poh with respect to Divisions. The figure presents the spices that are added in the soup to provide the taste characteristic of nah poh. F1 and F2 axes contribute to explain the use of these spices in the different divisions as spices responsible of the taste of nah poh at 91.89\%. Three of the spices are often consumed for their taste in Mezam and Lebialem Divisions, while five of them are consumed for the taste of nah poh in the rest of the regions. The spices grouped in the form of spot on the negative side of the axis are not used in the nah poh for the taste. UN: Upper Nkam; Mi: Mifi; UP: Upper Plateau; Mez: Mezam; KKi: Koung-Khi; N: Nde; Me: Menoua; Le: Lebialem; Bam: Bamboutos; Ba: Bansoa Hgb: H. gabonii (bark); Hgf: H. gabonii (fruits) Szf: S. zenkeri fruit

West Region. Generally, T. tetraptera, M. myristica, $H$. gabonii fruits, S. striatinux, X. africana, S. zenkeri fruits and $P$. guineense are the spices used to provide the taste of this soup. X. africana, S. zenkeri fruit and P. guineense are purposely used to enhanced the taste of nah poh in Mezam Division; P. guineense and $H$. gabonii fruits in Lebialem Division; $H$. gabonii fruits, $M$. myristica, $P$. guineense, T. tetraptera and S. striatinux in the different Divisions of the West Region. An aspect of the taste characteristics that the consumers require in nah poh can be attributed to mono- and sesquiterpenes, pinene and limonene which were described to be responsible to the pleasant aroma of essential oils of P. guineense. They release a flavour tending to that of clove, nutmeg, herbal/vegetable and fruity-like [15]. Figure 5 puts an emphasis on the use of T. tetraptera and M. myristica as spices responsible for the taste in the preparation of nah poh, taking into consideration their positions when projected on the F2 axis.

\section{Spices responsible of the odour of nah poh}

Taste and flavour/odour have been shown to play an important role in food choice and acceptance [16]. Unlike the taste of nah poh, specific spices are used to provide the odour that characterizes it. The spices responsible of the odour of nah poh with respect to the Division of residence are presented in Fig. 6.

There are three ways by which local spices are employed to provide the odour of nah poh in the West
Regions of Cameroon. In Mezam Division S. zenkeri fruit is often used for the odour; meanwhile $H$. gabonii fruit and bark are mostly used in Lebialem and the different Divisions of the West Region. Looking at Fig. 6, S. zenkeri fruits and H. gabonii fruits are used in Bamboutos for this purpose, thus the isolation of Bamboutos Division from the rest of the Divisions of the West Region. This might be due to geographical and historical reasons: The nearness of Mezam and Bamboutos and interaction of the populations in the past, as seen on Fig. 1. The barks of $H$. gabonii and S. zenkeri are rarely used in Mezam Division. These results are in accordance with those of Abdou Bouba [2] who underlined the fact that H. gabonii bark is almost not recognized in Mezam Division as a spice for yellow achu soup. Jirovertz et al. [17] and Songue et al. [18] showed that there is a link between S. zenkeri and H. gabonii at the chemical level. The two plant materials are rich in aromatic compounds containing sulphur bonds (6-(methylsulfonyl)-1,2,3dithiazinan-4-one or scorodophlone; sophoradiol (12oleanene-3,22-diol), lupeol Methyl; methylthiomethyl disulphide; Di-(thiomethylmethyl) disulphide) which are responsible for their garlic-like odour.

\section{Quantities of essential spices used for the preparation of nah poh}

The preparation of nah poh requires some spices that must be there to provide appropriate sensorial qualities. Table 4 presents the mean weights of each 
Biplot (axes F1 and F2: 98,27\%)

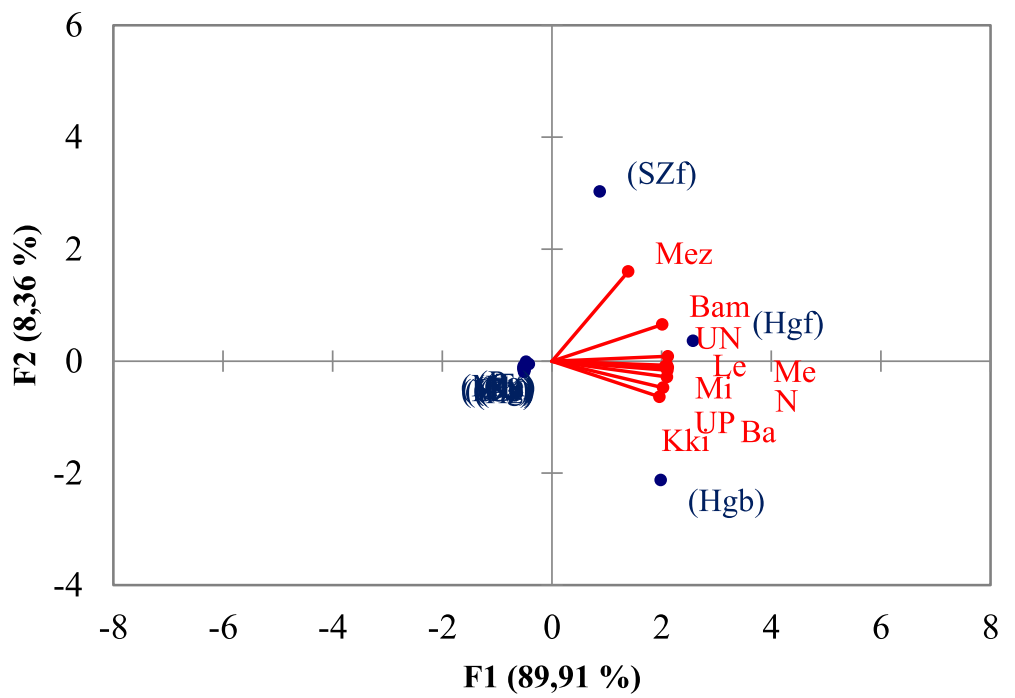

Fig. 6 Spices responsible of the odour of nah poh with respect to Divisions. The figure presents the spices used to provide the characteristic odour of nah poh. F1 and F2 axes contribute to explain the use of S. zenkeri fruit, H. gabonii (fruits) and H. gabonii (bark) as spices responsible of the odour of nah poh at $\mathbf{9 8 . 2 7 \%}$ in the different localities of the study area. S. zenkeri fruit is mostly used for the odour in Mezam and Bamboutos Divisions, while H. gabonii (fruits) and H. gabonii (bark) are preferred in the rest of the divisions. UN: Upper Nkam; Mi: Mifi; UP: Upper Plateau; Mez: Mezam; KKi: Koung-Khi; N: Nde; Me: Menoua; Le: Lebialem; Bam: Bamboutos; Ba: Bansoa Hgf: H. gabonii fruits; Mm: M. myristica; Pg: P. guineense; Ss: S. striatinux; Szf: S. zenkeri fruit; Tt: T. tetraptera: Xa: X. africana

essential spice in grammes, for the preparation of 11 of nah poh with respect to the different Divisions. The mean weights of the values obtained for each essential spice were computed automatically with the aid of Sphinx software.

Table 4 shows that the standard deviations of most of the mean weights of the local spices are very high and this illustrates the fact that the variability is not only at the level of the types of spices used, but also at the level of the quantity of each of these spices, when it comes to nah poh preparation in the different localities of the West Regions of Cameroon. It is the case with P. guineense, $H$. gabonii fruits, M. myristica and S. striatinux. The weights of essential spices used for the preparation of nah poh varied between $0.61 \pm 0.24 \mathrm{~g}$ for $S$. zenkeri fruits in Koung-Khi Division to $4.59 \pm 2.06 \mathrm{~g}$ for T. tetraptera in Upper Plateau Division for 11 of nah poh. The quantity of each the spices used by these households per litre of nah poh falls almost within the same range with that of individual spices consumed per day in similar

Table 4 Mean weights (g) of essential spices for the preparation $1 \mathrm{~L}$ of nah poh

\begin{tabular}{|c|c|c|c|c|c|c|c|}
\hline \multirow[t]{2}{*}{ Divisions } & \multicolumn{7}{|l|}{ Spices } \\
\hline & $\mathrm{Hgf}$ & $\mathrm{Mm}$ & $\mathrm{Pg}$ & Ss & Szf & $\mathrm{Xa}$ & $\mathrm{Tt}$ \\
\hline UN & $2.71 \pm 1.22$ & $1.62 \pm 1.53$ & $1.67 \pm 1.09$ & $2.06 \pm 1.39$ & $1.23 \pm 0.65$ & $1.13 \pm 0.00$ & $4.13 \pm 2.61$ \\
\hline $\mathrm{Mi}$ & $2.89 \pm 1.32$ & $2.02 \pm 1.16$ & $1.94 \pm 1.90$ & $2.55 \pm 1.91$ & $1.86 \pm 1.00$ & $1.53 \pm 0.89$ & $4.36 \pm 2.11$ \\
\hline UP & $2.95 \pm 1.76$ & $2.13 \pm 1.05$ & $1.98 \pm 0.95$ & $2.72 \pm 1.44$ & $1.37 \pm 0.93$ & $1.50 \pm 0.00$ & $4.48 \pm 2.26$ \\
\hline Mez & $1.63 \pm 1.21$ & $1.30 \pm 0.84$ & $1.11 \pm 0.88$ & $1.04 \pm 0.68$ & $1.37 \pm 0.76$ & $1.55 \pm 1.02$ & $1.34 \pm 0.91$ \\
\hline Kki & $2.36 \pm 1.29$ & $1.89 \pm 0.89$ & $2.02 \pm 1.55$ & $1.96 \pm 1.13$ & $0.61 \pm 0.24$ & $0.00 \pm 0.00$ & $4.59 \pm 2.06$ \\
\hline N & $2.72 \pm 1.68$ & $1.49 \pm 0.83$ & $3.99 \pm 3.00$ & $1.79 \pm 0.81$ & $0.84 \pm 0.35$ & $0.83 \pm 0.40$ & $3.66 \pm 1.98$ \\
\hline $\mathrm{Ba}$ & $2.17 \pm 1.13$ & $1.87 \pm 0.99$ & $1.01 \pm 0.78$ & $1.34 \pm 1.12$ & $1.45 \pm 0.71$ & $1.25 \pm 0.00$ & $3.53 \pm 2.08$ \\
\hline $\mathrm{Me}$ & $3.04 \pm 1.68$ & $1.57 \pm 1.17$ & $1.10 \pm 0.79$ & $2.40 \pm 2.29$ & $1.70 \pm 1.28$ & $1.46 \pm 1.77$ & $3.04 \pm 1.85$ \\
\hline Le & $2.20 \pm 0.97$ & $1.51 \pm 1.03$ & $1.05 \pm 0.76$ & $1.55 \pm 1.20$ & $1.82 \pm 1.10$ & $1.44 \pm 1.01$ & $2.45 \pm 2.00$ \\
\hline Bam & $2.16 \pm 1.04$ & $1.31 \pm 1.30$ & $1.07 \pm 0.88$ & $1.04 \pm 0.67$ & $1.57 \pm 0.87$ & $0.79 \pm 0.51$ & $2.19 \pm 1.41$ \\
\hline
\end{tabular}

UN: Upper Nkam; Mi: Mifi; UP: Upper Plateau; Mez: Mezam; KKi: Koung-Khi; N: Nde; Me: Menoua; Le: Lebialem; Bam: Bamboutos; Ba: Bansoa; Hgf: H. gabonii fruits; Mm: M. myristica; Pg: P. guineense; Ss: S. striatinux; Szf: S. zenkeri fruit; Tt: T. tetraptera: Xa: X. africana. The values are means of the following number of repetitions: Hgf (411); Mm (458); Pg (462); Ss (306); Szf (291); Xa (129); Tt (410) 


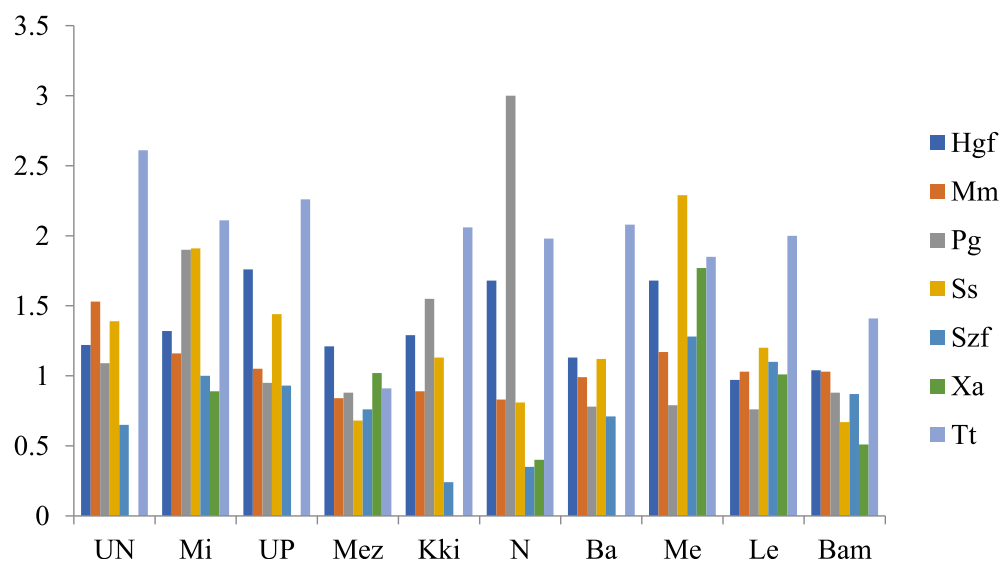

Fig. 7 Variation of the standard deviations of essential spices for nah poh in the different Divisions. The figure presents the variability in the use of essential spices in the different divisions of the study area. X. africana is consumed as essential spice only in Mezam and Lebialem Divisions. This figure shows that from a division to the other, there is a variability in the way of using essential spices for the preparation of nah poh. In Nde some people consume very high quantity of $P$. guineense while others use very small quantities

study in North Eastern Nigeria and South India [11, 19]. This shows a similarity in the way of quantifying spices for culinary practices between the populations of Western high land Regions of Cameroon, North Eastern Nigeria and those of South India.
Figure 7 is the representation of the standard deviations of the mean weights of each spice used for the preparation of nah poh in the different Divisions of West Regions of Cameroon. These differences on the standard deviations of the mean weights of spices used for the
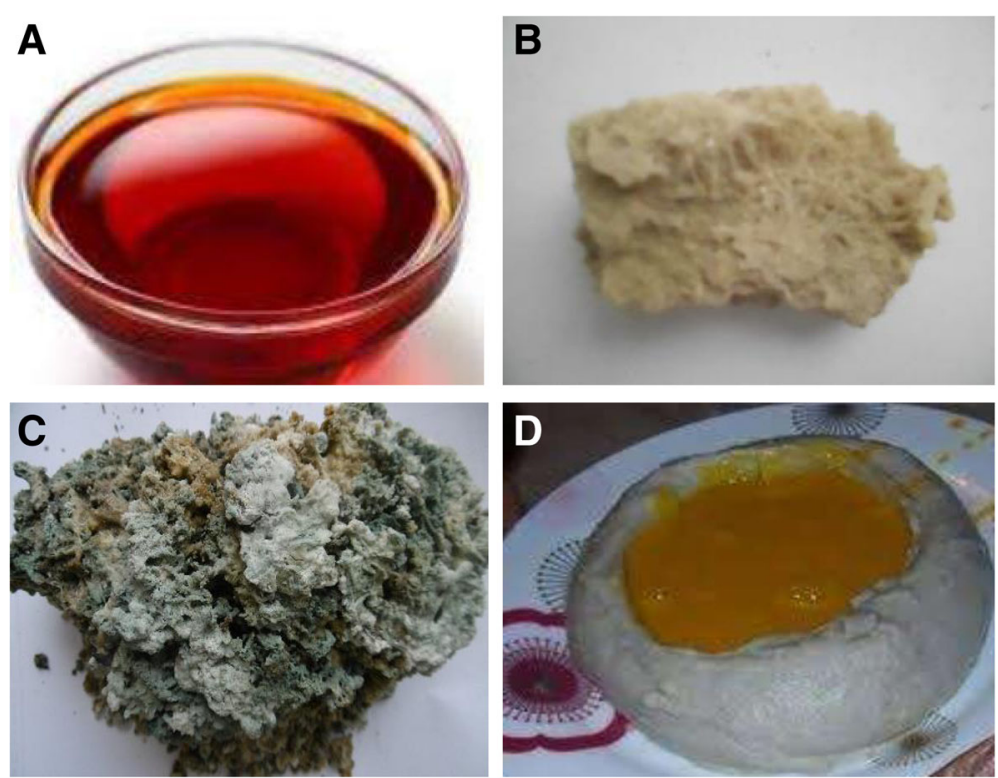

Fig. 8 a Crude palm oil is one of the main components for the preparation of the nah poh. It is produced from the fruit Elaeis guineensis. Far back in the past when roads were not available, it was a valuable food product in the western high land regions of Cameroon where nah poh originated. It is one of the reasons while a cultural value is attached to nah poh up till our days. b Kanwa is the name given to natron in the western highland regions of Cameroon, were it is used as emulsifying agent for the preparation of nah poh. It is also used for the preparation of many traditional dishes. It is a lake deposit and is used to eliminate toxic secondary metabolites from foods during preparation. c Niky is a processed emulsifying agent which is used to substitute kanwa. It is preferred by certain ethnic groups over kanwa. It is obtained from incineration of dried banana peeling under controlled oxygen conditions. The form of niky presented here is mostly produced in the North-West Region. In other places, ash extracted is used to substitute as niky. d A plate of achu and nah poh. Nah poh is the yellow liquid at the centre, and achu the white paste. This is how the meal is usually arranged in the plate for consumption; it is the traditional way of doing it. This way of serving the meal is respected in all the places where nah poh is offered by a person from the western highland regions of Cameroon all over the world 
preparation of nah poh in the various Divisions illustrate the variability that exists in the use of these spices. In Nde Division for example, there are women who use much $P$. guineense than others. Variations in the way local spices are used in nah poh are observed with all the spices (Fig. 8). T. tetraptera, S. striatinux and P. guineense are the spices which present the most visible variations. The standard deviation of $X$. africana is more pronounced in Mezam Division compared to the other Divisions. Considering the study of Uma et al. [19] it can be deduced that there is a high variation in the quantity of various spices in a spice mix when they are used for cooking purpose. Results of the present study are therefore in line with available data in the literature. The high variation of the quantity of $X$. africana in this Division is due to the fact that many people knew this spice in Mezam Division (94.1\%), and this increased the chances of having differences on the weight proposed.

\section{Conclusion}

The type and quantity of spices used for the preparation of nah poh varied a lot in the Western Regions of Cameroon, depending on the food habits of the different population groups. The variability in the spice composition of nah poh is mostly based on the sensorial properties (taste and odour) that are taken into consideration during the preparation. Essential spices for the taste and those employed to provide the odour of nah poh could be divided into three groups. In the West Region, there is a similarity in the way local spices are used for the preparation of nah poh. Besides the variability in the types and quantities of spices used, $X$. africana and $S$. zenkeri fruits are mainly responsible for the difference in making spice mixes for nah poh in Mezam and the rest of the Divisions. The mastery of these variabilities in the way households make the spice mix of nah poh is a step forward for the development of a modernized spice blend for all consumers for nah poh.

\footnotetext{
Acknowledgements

The authors are grateful to:

-Doctor Maths Mazra, Head of the Department of Management Science of the University of Maroua for the contribution to the conception of the questionnaire form used in this work, and for the statistical analysis. -Professor Pierre M. Maponmetsem Head of Department of Plant Biology of the University of Ngaoundere, for the identification of some of the spice samples used for the survey.

-His majesty Patrice Kenfack Tanga II Fouotsop, Paramount chief of Balatchi for hospitality in this palace and chiefdom.

- To the traditional rulers and women of Bangang, Bafut, Nkwen and Foto palaces for contributing and facilitating the work in their respective chiefdoms.

-To all the women who freely committed their time to take part in the survey.
}

\section{Authors' contributions}

SD: 25\%, LBMK: 30\%, LM: 5\%, CT: 35\%. All authors read and approved the final manuscript.
Availability of data and materials

Not applicable.

\section{Competing interests}

The authors declare that they have no competing interests.

\section{Author details}

${ }^{1}$ Department of Food Sciences and Nutrition, National Advanced School of Agro-Industrial Sciences (ENSAI), University of Ngaoundere, PO Box 455, Ngaoundere, Cameroon. ${ }^{2}$ Department of Agriculture, Breeding and Derived Products, National Advanced School of Engineering, University of Maroua, PO Box 46, Maroua, Cameroon. ${ }^{3}$ Laboratory of Biomolecular Engineering, National Advanced School of Agronomy and Industrial Food (ENSAIA), National Institute of Polytechnic of Lorraine (INPL), 54500 Vandoeuvre-lès-, Nancy, France.

Received: 30 June 2019 Accepted: 21 November 2019

Published online: 28 December 2019

\section{References}

1. Raschke VU, Oltersdorf I, Elmadfa ML, Wahlqvist BSB, Cheema A, Kouris-Blazos A. Content of a novel online collection of traditional east African food habits (1930s - 1960s): data collected by the MaxPlanck-Nutrition Research Unit, Bumbuli, Tanzania. Asia Pac J Clin Nutr. 2007:16(1):140-51.

2. Abdou-Bouba A. Contribution à l'étude du développement d'un aliment fonctionnel à base d'épices du Cameroun: Caractérisation physicochimique et fonctionnelle, Thèse présentée à l'Institut National Polytechnique de Lorraine et à I'Université de Ngaoundéré en vue d'obtention du titre de Docteur de L'INPL et Docteur Ph D de I'Université de Ngaoundéré (Cameroun). 2009; p 223.

3. Suleyman MD, African indigenous food crops: their roles in combatting chronic diseases in Ghana. Thesis submitted in conformity with the requirements for the degree of Master of Arts Department of Social Justice Ontario Institute for Studies in Education University of Toronto-Canada. 2014; p143.

4. Prabhakar PK, Srivastav PP. Characterization of soru-chakli- A traditional food of West Bengal. Food Sci Technol. 2015;1(2):1-8.

5. Tchiégang C, Mbougueng PD. Composition chimique des épices utilisées dans la préparation du nah poh et du nkui de l'Ouest Cameroun. Tropicultura. 2005;23(4):193-200.

6. Abdou-Bouba A, Njintang YN, Scher J, Mbofung CMF. Phenolic compounds and radical scavenging potential of twenty Cameroonian spices. Agric Biol J North Am. 2010;1(3):213-24.

7. Abdou-Bouba A, Njintang YN, Foyet HS, Scher J, Montet D, Mbofung CMF. Proximate composition, mineral and vitamin content of some wild plants used as spices in Cameroon. Food Nutr Sci. 2012:3:423-32.

8. Lawless LJR, Hottenstein A, Ellingsworth J. The mccormick spice wheel: a systematic and visual approach to sensory lexicon development. J Sensor Stud. 2012;27:37-47

9. Spence C. Crossmodal contributions to the perception of piquancy/ spiciness. Journal of Sensory Studies. 2019;34:e12476 https://doi.org/10. $1111 /$ joss. 12476

10. Nana-Ngassam T. Contribution à la connaissance de la composition en épices entrant dans les préparations du nah poh et du nkui. Mémoire présenté en vue de l'obtention du Diplôme de Professeur d'Enseignement Secondaire $\|^{e}$ Grade, Ecole Normale Supérieure, Université de Yaoundé I (Cameroun). 1997; p49.

11. Badau MH, Igene JO, Collison EK, Nkama I. Studies on production, Physicochemical and sensory properties of a standard kilishi ingredient mix powder. Int J Food Sci Nutr. 1997:48:165-8.

12. WWF. (World Wild Fund for Nature) and IUCN (World Nature Conservation). Centres of plant diversity, A guide and strategy for their conservation vol.1. Cambridge: IUCN publication units; 1994. p. 335

13. CHeek M. Xylopia africana. The IUCN Red List of Threatened Species: 2014 e.T45423A3001846https://doi.org/10.2305/IUCN.UK.20143.RLTS. T45423A3001846.en

14. Modi VK, Sidde GSG, Sakhare PZ, Mahendrakar NS, Narasimha DR. Preprocessed spice mix formulation and changes in its quantity during storage. Food Sci Technol. 2006;39:613-20. 
15. Jirovetz L, Buchbauer G, Ngassoum MB, Geissler M. Aroma compound analysis of Piper nigrum and Piper guineense essential oils from Cameroon using solid-phase microextraction-gas chromatography, solid-phase microextraction-gas chromatography-mass spectrometry and olfactometry. J Chromatography A. 2002;976(2):265-75.

16. Clark JE. Taste and flavour: their importance in food choice and acceptance. Proc Nutr Soc. 1998;57:639-43.

17. Jirovetz L, Buchbouer G, Ngassoum MB, Geissler M. Analysis of headspace aroma compound of the seeds of the Cameroonian 'garlic plant' H. gabonii using SPME/ GC/FID SPME/ GC/ MS and alfactometry. J Eur Food Res Technol. 2002:214:212-5.

18. Songue JL, Azebaze AGB, Vardamides JC, Ndom JC, Meyer AM, Dongo E, et al. A novel alkylsulfone from the seeds of Scorodophloeus zenkeri. Bull Chem Soc Ethiopia. 2006;20(1):173-6.

19. Uma Pradeep K, Geervani P, Eggum BO. Common Indian spices: Nutrients composition, consumption and contribution to dietary value. Plant Foods Hum Nutr. 1993:44:137-48.

\section{Publisher's Note}

Springer Nature remains neutral with regard to jurisdictional claims in published maps and institutional affiliations.

Ready to submit your research? Choose BMC and benefit from:

- fast, convenient online submission

- thorough peer review by experienced researchers in your field

- rapid publication on acceptance

- support for research data, including large and complex data types

- gold Open Access which fosters wider collaboration and increased citations

- maximum visibility for your research: over $100 \mathrm{M}$ website views per year

At $\mathrm{BMC}$, research is always in progress.

Learn more biomedcentral.com/submissions 